\title{
The impact of disturbance intensity on spatial variability of habitat conditions and seedling recruitment of selected rare, medicinal plants in Molinion patches
}

\author{
Kinga Kostrakiewicz-Gieralt \\ Department of Natural Environmental Studies, Faculty of Tourism and Recreation, \\ University of Physical Education in Krakow, Jana Pawła II 78, 31-571 Kraków, Poland \\ e-mail: kinga.kostrakiewicz@awf.krakow.pl
}

Received: 20 January 2019 / Accepted: 1 March 2019

\begin{abstract}
The investigations were conducted in two Molinion patches dominated by small meadow species (ME) and overgrown by tall-growing macroforbs (MAC). Observations were carried out in systematically arranged permanent experimental plots divided in subplots. The subplots were subjected to: I) no disturbances; II) low level of disturbance, corresponding with trampling consisting of the litter and moss layer removal; III) intermediate level of disturbance, corresponding with mowing consisting of the litter, moss, and above-ground part of plants removal; and IV) high level of disturbance, corresponding with rooting by wild mammals consisting of the litter, moss and the plants removal, as well as top soil raking with a metal scraper about $7 \mathrm{~cm}$ deep. The light availability was greater in Patch ME, while the soil humidity achieved higher values in Patch MAC. At the same time, the light availability increased in consecutive subplots, whereas the soil humidity showed a reversed trend. The cumulative number of seedlings Betonica officinalis and Succisa pratensis in Patches ME and MAC was similar, while Sanguisorba officinalis recruited more abundantly in Patch ME. The greatest number of offspring of all studied taxa was noticed in subplots III and IV. The obtained results might contribute to creating of succesful plans of enlargement of natural resources of medicinal plants in Molinia meadows-one of most valuable seminatural communities in Europe.
\end{abstract}

Key words: animal activity; gaps; human activity; management; medicinal plant; recolonisation; succession.

\section{Introduction}

A disturbance is a temporary change in environmental conditions that causes a pronounced change in an ecosystem. Large-scale abiotic ecological disturbances such as fires, flooding, windstorms, various types of volcanic eruptions, tsunamis and firestorms act quickly and with great effect to alter the physical structure or arrangement of ecosystem elements. Small-scale biotic disturbances, originating as an effect of animals (such as browsing, wallowing, trampling, grazing, raking) or human activity (trampling, mowing), contribute to the appearance of openings in continuous plant cover acting as 'safe sites for seedling recruitment' (sensu Harper et al., 1965) and 'windows of opportunity' (sensu Eriksson \& Fröborg, 1996) i.e. spatially or temporally unpredictable conditions in which seedling recruitment is possible within stands of established conspecific adults. The occurrence of gaps is particularly valuable in semi-natural communities subjected to overgrowing and transformations in the course of secondary succession. Such habitats are represented inter alia by Molinia meadows designated for conservation by International Conventions (Anonymous, 1992; 1997), and included in the NATURA 2000 network (Anonymous, 2007).

To date, numerous authors have observed seedling recruitment after artificial seed addition in gaps 
(e.g. Křenová \& Lepš, 1996; Špačková et al., 1998; Kotorová \& Lepš, 1999; Isselstein et al., 2002; Těšitel et al., 2017). Other investigators have focused on natural seedling recruitment, especially on the relations among species composition in the plant canopy, seed rain and seedling pool (Kostrakiewicz-Gierałt, 2017a; 2017b; 2018). Moreover, spontaneous seedling recruitment was observed in gaps occurring as a result of disturbances characterised by different size (Kostrakiewicz, 2011; Kostrakiewicz-Gierałt, 2014a; 2014b), time of creation (Mudrák et al., 2013; Kostrakiewicz-Gierałt, 2015a), shape (KostrakiewiczGierałt, 2015b) and intensity (e.g. Lepš, 1999; Špačková \& Lepš, 2004; Janeček \& Lepš, 2005; Mudrák et al., 2013; Lepš, 2014). Despite the growing interest in the influence of disturbance intensity on natural gap recolonisation, the spontaneous seedling recruitment of particular species has only been rather rarely investigated (e.g. Špačková et al., 1998; Kubíková \& Zeidler, 2011; Kostrakiewicz-Gierałt, 2012; 2014a).

Considering this, the present studies were undertaken aimed at assessing the effect of disturbance intensity on the spatial variability of habitat conditions and natural recruitment of seedlings of the rare, declining in Europe medicinal plants Betonica officinalis, Sanguisorba officinalis and Succisa pratensis in Molinia meadows representing different successional stages.

\section{The study area}

The investigations were carried out in Kraków-Kostrze, Southern Poland (Fig. 1A) in a study area consisting of two adjacent abandoned patches of Molinion caeruleae sensu Matuszkiewicz (2008), measuring ca. $2300 \mathrm{~m}^{2}$ and differing as to successional stage and dominant species. Patch $\mathrm{ME}$, representing the initial successional stage, was dominated by meadow species creating delicate erect (up to $30 \mathrm{~cm}$ ) or procumbent stems such as Lotus corniculatus, Lychnis flos-cuculi, Potentilla erecta and Lathyrus pratensis. Patch MAC, representing advanced successional stage, was overgrown by tall-growing macroforbs (e.g. Filipendula ulmaria, Lysimachia vulgaris and Lythrum salicaria). Within the aforementioned Patch the large tussock and rhizomatous grasses e.g Phragmites australis, Deschampsia caespitosa, Molinia caerulea and shrub-willows such as Salix repens ssp. rosmarinifolia and Salix cinerea were also abundant. The characteristics of the study Patches are given in Table 1.

Table 1. The characteristics of study Patches

\begin{tabular}{lcc}
\hline & Patch ME & Patch MAC \\
\hline Area $\left(\mathrm{m}^{2}\right)$ & 2300 & 2300 \\
\hline Coordinates & $\begin{array}{c}50^{\circ} 01^{\prime} 55.7^{\prime \prime} \mathrm{N} ; \\
19^{\circ} 52^{\prime} 03.1^{\prime \prime} \mathrm{E}\end{array}$ & $\begin{array}{c}50^{\circ} 01^{\prime} 55.2^{\prime \prime} \mathrm{N} ; \\
9^{\circ} 52^{\prime} 05.5^{\prime \prime} \mathrm{E}\end{array}$ \\
\hline & $\begin{array}{c}\text { Lotus corniculatus, } \\
\text { Lychnis flos-cuculi, } \\
\text { Potentilla erecta }\end{array}$ & $\begin{array}{c}\text { Lysimachia vulgaris, Filipendula } \\
\text { ulmaria, } \\
\text { Phragmites australis, Deschampsia } \\
\text { caespitosa, }\end{array}$ \\
\hline Subdominant species & Lathyrus pratensis, Selinum \\
carvifolia, & $\begin{array}{c}\text { Salix cinerea, }, \\
\text { Molinia caerulea }\end{array}$ \\
\hline Number of generative stems Betonica officinalis & Betonica officinalis & Sanguisorba officinalis \\
\hline Number of generative stems Succisa pratensis & 132 & 95 \\
\hline Number of generative stems Sanguisorba officinalis & 148 & 88 \\
\hline The cover of trees and shrubs (\%) & 117 & 76 \\
\hline The cover of herbaceous vegetation (\%) & 0 & 15 \\
\hline The cover of bryophytes $(\%)$ & 98 & 100 \\
\hline The mean ( \pm SD) height of the highest stems (cm)* & 5 & 10 \\
\hline
\end{tabular}




\section{Material and methods}

\subsection{The study species}

All the studied species belong to hemicryptophytes (Pladias, 2014-2018), propagating clonally affiliated to patches of Molinia meadows: Betonica officinalis and Succisa pratensis representing characteristic species for the Molinion caeruleae alliance, while Sanguisorba officinalis is a characteristic species for the Molinietalia order (Matuszkiewicz, 2008). The studied species represent rare plants included into many regional or national Red Lists or Books (e.g. Wilhalm \& Hilpold, 2006; Sparrius et al., 2014; Stroh et al., 2014; Bornand et al., 2016; Wyse Jackson et al., 2016).

Betonica officinalis L. syn. Stachys officinalis (L.) Trevis (Lamiaceae), naturally occurring in Europe and Western Asia (Anonymous, 1998a), has been used for centuries for the treatment of disorders of the respiratory, gastrointestinal tract, cerebral afflictions, high blood pressure, skin ulcers, as well as gynecological problems (Lazarević et al., 2013). This species represents rhizomatous plants creating rosettes of leaves and upright flowering stems growing up to $90 \mathrm{~cm}$, topped by interrupted spikes formed by several rings or whorls of bright, purple-red or occasionally white flowers pollinated by bumblebees (mostly Bombus pascuorum). One inflorescence might produce between 100 to 1.000 seeds dispersed by water and animals (Kleyer et al., 2008). The unspecialised seeds are mostly disseminated in summer and autumn, the mean density of soil seedbank amounts to ca. 41 seeds per $1 \mathrm{~m}^{2}$, and its longevity reaches 3 - 12 months (Fitter \& Peat, 1994). The germination ability of seeds in laboratory conditions ranged from 50\% to 100\% (Royal Botanic Gardens Kew, 2018).

Succisa pratensis Moench. (Scabiosa succisa L.) (Dipsacaceae), natively occurring in Europe and Western Siberia (Anonymous, 1997), has demulcent, depurative, slightly diaphoretic, diuretic and anti-inflammatory properties. The antimicrobial and antioxidant activity of the essential oils was confirmed by Witkowska-Banaszczak and Długaszewska (2017). The individuals form a short vertical rhizome bearing a rosette of leaves. The flowering stems usually carry up to six - but occasionally more - flower heads with up to 100 small, pale violet flowers (Adams, 1955). Most seeds land close to the mother plant, but longdistance dispersal by animals, water or wind is likely to occur (Kleyer et al., 2008). The unspecialised seeds might be dispersed in summer and autumn and build the transient seed bank achieving ca. 302 seeds per $1 \mathrm{~m}^{2}$ (Fitter \& Peat, 1994; Kleyer et al., 2008). The germination ability of seeds sown in laboratory conditions ranged from $75 \%$ to $100 \%$ (Royal Botanic Gardens Kew, 2018).

Sanguisorba officinalis L. (Rosaceae), whose native distribution includes the Americas, Asia and Europe
(Anonymous, 1998b), is well known as a traditional herbal medicine to treat inflammation and allergic skin diseases (Su et al., 2018), as well as wounds (Zhang et al., 2018). Individuals create a basal rosette of odd-pinnate leaves and an erect flowering stem with several terminal inflorescences containing up to 100 flowers, pollinated by bees, syrphid flies, muscid flies and butterflies (including the endangered large blue butterfly species: Maculinea nausithous and $M$. teleius). The inflorescence might produce from 52 to 94 seeds dispersed by animals, water or wind building up transient soil banks achieving ca. 48 seeds per $1 \mathrm{~m}^{2}$ (Kleyer et al., 2008; Fitter \& Peat, 1994). The germination ability of seeds sown in laboratory conditions ranged from 59\% to 95\% (Royal Botanic Gardens Kew, 2018).

\subsection{The experimental design}

In both patches in April 2017 twelve permanent experimental plots were systematically arranged. The experimental plots were established in 4 rows, each row containing 3 plots. They were established at least $5.0 \mathrm{~m}$ from the border of the patch to avoid the edge effect. Each plot was divided in four square-shaped, separate subplots of $0.5 \mathrm{~m} \times 0.5 \mathrm{~m}$. The subplots were subjected to four different disturbance regimes: I) no disturbances; II) low level of disturbance, corresponding with trampling consisting of the litter and moss layer removal; III) intermediate level of disturbance, corresponding with mowing consisting of the litter, moss, and above-ground part of plants removal; and IV) high level of disturbance, corresponding with rooting by wild mammals consisting of the litter, moss and the plants removal, as well as top soil raking with a metal scraper about $7 \mathrm{~cm}$ deep. The experimental design is presented in Figure $1 \mathrm{~B}, \mathrm{C}$.

The light intensity and soil humidity in the openings were evaluated on the basis of measurements conducted in the central part of each gap. In order to make the obtained microclimatic data spatially and temporally comparable, the measurements were taken in full vegetation development and in similar weather conditions (especially the lack of precipitation in the 3-day period before the measurements). Moreover, the measurements were conducted in full sun exposure between the hours of 10.00 a.m. and 12.00 noon on 8 June 2017 and on 9 June 2018. Light intensity was measured using LX-1010B Digital Light Lux Meter (measuring range of light intensity 0.1-2000.0 lx), while soil humidity was measured using a digital TZSI sensor (measuring range of soil humidity 1-100\%) The generative offspring establishment was monitored once a week in May, June, July and August, and once every two weeks in April, September and October, from 2017 through 2018. Seedlings were counted in each subplot. The seedlings were removed and determined according to Csapodý 


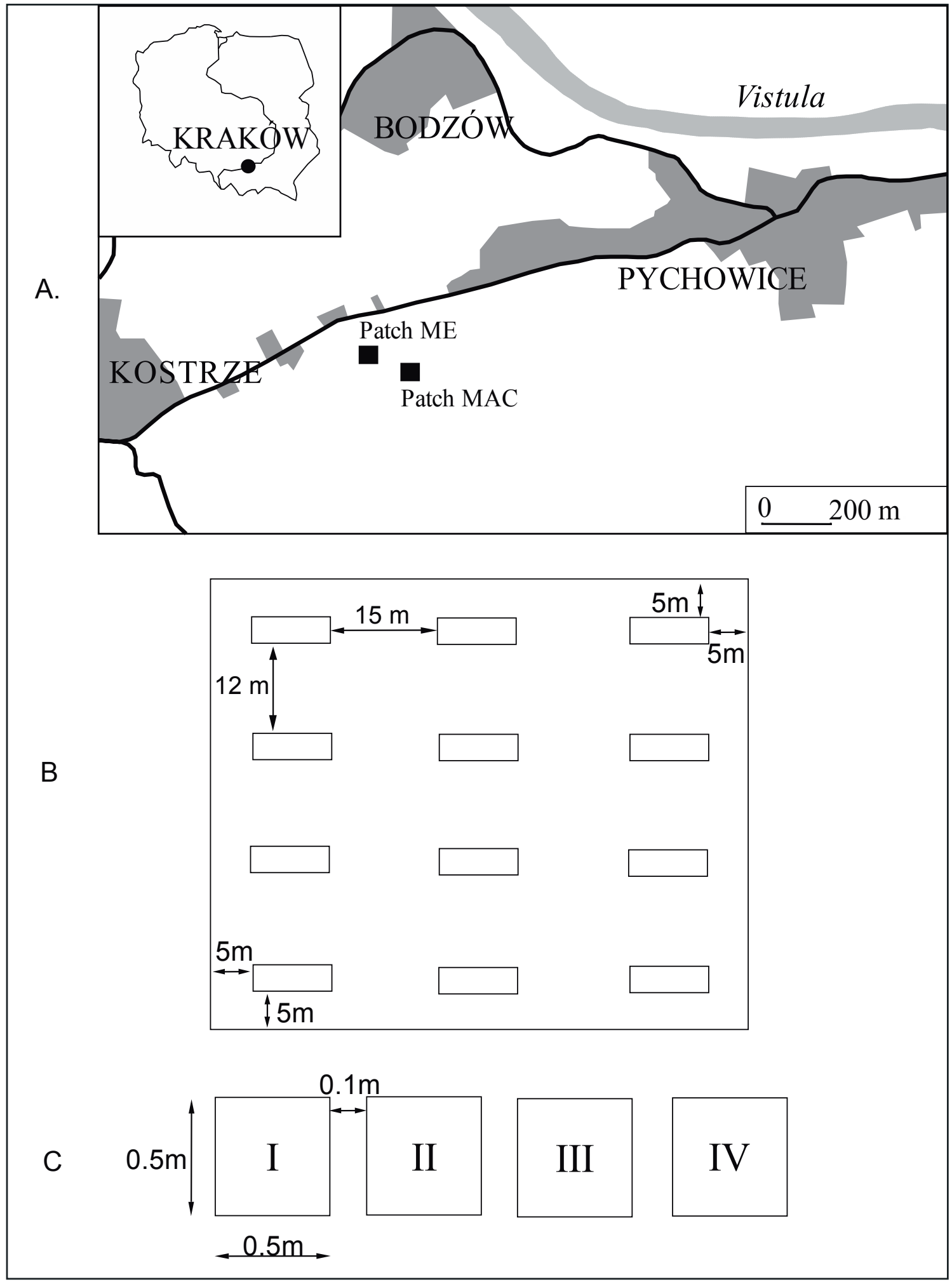

Figure 1. The locality of study area and experimental design. A-locality of study Patch dominated by small meadow species (ME) and prevailed by tall-growing macroforbs (MAC); B- pattern of distribution of study plots within Patches ME and MAC; C-pattern of distribution of subplots within plots: I- subplot with no disturbance, II- subplot with removed litter and mosses, III- subplot with removed litter, mosses and aboveground organs of plants, IV- subplot with removed litter, mosses, aboveground organs of plants and $7 \mathrm{~cm}$ soil layer 
(1968) and Muller (1978) with the support of a comparative collection.

\subsection{Statistical analysis}

The ANOVA analysis for factorial design and the Tukey HSD test were applied to check the statistical significance of the effect of the patch character and disturbance intensity on: (i) the light intensity and the soil moisture in the year 2017 and 2018, as well as (ii) the cumulative number of seedlings Betonica officinalis, Sanguisorba officinalis and Succisa pratensis appearing in whole study period. All the analyses were computed using STATISTICA software (version 13).

\section{Results}

\subsection{The habitat conditions}

The light intensity at the ground level achieved greater values in Patch ME, than in Patch MAC in both study years. Moreover, it increased from subplot I via II to III and IV (Table 2). The statistical analysis confirmed the remarkable effect of patch character and subplot type on light intensity (Table 3). The Tukey HSD test showed the significant differences among Patches $(\mathrm{p}<0.001)$. Moreover, it showed the remarkable differences among subplot I and subplots III, IV $(\mathrm{p}<0.001)$, as well as among subplot II and subplot IV $(\mathrm{p} \leq 0.05)$ within both study sites. The soil

Table 2. The mean ( $\pm \mathrm{SD}$ ) light intensity (Lx) in gaps in subplots with no disturbance (I), removed litter and mosses (II), removed litter, mosses and aboveground organs of plants (III), removed litter, mosses aboveground organs of plants and $7 \mathrm{~cm}$ soil layer (IV) in Molinion caeruleae patch dominated by small meadow taxa (ME) and overgrown by macroforbs (MAC) in the years 2017 and 2018

\begin{tabular}{|c|c|c|c|c|c|}
\hline & & \multicolumn{4}{|c|}{ Subplots } \\
\hline & & I & II & III & IV \\
\hline \multirow[t]{2}{*}{ Year 2017} & ME & $\begin{array}{c}1633.3 \\
( \pm 137.1)\end{array}$ & $\begin{array}{c}1700.0 \\
( \pm 112.8)\end{array}$ & $\begin{array}{l}1800.0 \\
( \pm 95.3)\end{array}$ & $\begin{array}{l}1808.3 \\
( \pm 99.6)\end{array}$ \\
\hline & MAC & $\begin{array}{c}1400.0 \\
( \pm 127.9)\end{array}$ & $\begin{array}{c}1508.3 \\
( \pm 124.0)\end{array}$ & $\begin{array}{c}1641.7 \\
( \pm 162.1)\end{array}$ & $\begin{array}{c}1650.0 \\
( \pm 156.7)\end{array}$ \\
\hline \multirow[t]{2}{*}{ Year 2018} & ME & $\begin{array}{c}1583.3 \\
( \pm 146.7)\end{array}$ & $\begin{array}{c}1650.0 \\
( \pm 108.7)\end{array}$ & $\begin{array}{c}1758.3 \\
( \pm 108.4)\end{array}$ & $\begin{array}{l}1775.03 \\
( \pm 128.8)\end{array}$ \\
\hline & MAC & $\begin{array}{c}1333.3 \\
( \pm 149.7)\end{array}$ & $\begin{array}{c}1450.0 \\
( \pm 138.2)\end{array}$ & $\begin{array}{c}1600.0 \\
( \pm 175.8)\end{array}$ & $\begin{array}{c}1608.3 \\
( \pm 173.0)\end{array}$ \\
\hline
\end{tabular}

Table 3. The ANOVA results for factorial designs of the effect of patch and subplot character on light intensity at ground level in the years 2017 and 2018

\begin{tabular}{|c|c|c|c|c|c|c|}
\hline & & Sum of squares & $\begin{array}{c}\text { Degrees } \\
\text { of freedom }\end{array}$ & Mean square & F-value & p-value \\
\hline \multirow[t]{5}{*}{ Year 2017} & Intercept & 259055104 & 1 & 259055104 & 15569.8 & $\mathrm{p}<0.001$ \\
\hline & Patch & 825104 & 1 & 825104 & 49.5 & $\mathrm{p}<0.001$ \\
\hline & Subplot & 742812 & 3 & 247604 & 14.8 & $\mathrm{p}<0.001$ \\
\hline & Patch*subplot & 22812 & 3 & 7604 & 0.4 & 0.56 \\
\hline & Error & 1464167 & 88 & 16638 & & \\
\hline \multirow[t]{5}{*}{ Year 2018} & Intercept & 244162604 & 1 & 244162604 & 11909.2 & $\mathrm{p}<0.001$ \\
\hline & Patch & 900938 & 1 & 900938 & 43.9 & $\mathrm{p}<0.001$ \\
\hline & Subplot & 891146 & 3 & 297049 & 14.4 & $\mathrm{p}<0.001$ \\
\hline & Patch*subplot & 31146 & 3 & 10382 & 0.5 & 0.44 \\
\hline & Error & 1804167 & 88 & 20502 & & \\
\hline
\end{tabular}


humidity was higher in Patch MAC. Additionally in botch study sites it decreased from subplot I via II to III and IV (Table 4). The statistical analysis confirmed the remarkable effect of patch character and subplot type on soil humidity (Table 5). The Tukey HSD test showed the significant differences among Patches $(p<0.001)$, as well as among subplot I and subplots III, IV ( $<<0.001)$, as well as among subplot II and subplots III $(\mathrm{p} \leq 0.05)$, IV $(\mathrm{p}<0.001)$ in both study sites.

\subsection{The seedling recruitment}

The cumulative number of seedlings Betonica officinalis and Succisa pratensis in Patches ME and MAC was similar (Table 6). Also, the statistical analysis confirmed significant effect of subplot type on abundance of recruits (Table 7). The Tukey HSD test showed the remarkable differences in recruitment of Betonica officinalis among subplot I and subpolots III, IV $(\mathrm{p}<0.001)$, as well as among subplot II and subplots III, IV $(\mathrm{p}<0.001)$, while the recruitment of Succisa pratensis differed significantly $(\mathrm{p}<0.001)$ among

Table 4. The mean $( \pm \mathrm{SD})$ soil humidity (\%) in gaps in subplots with no disturbance (I), removed litter and mosses (II), removed litter, mosses and aboveground organs of plants (III), removed litter, mosses aboveground organs of plants and $7 \mathrm{~cm}$ soil layer (IV) in Molinion caeruleae patch dominated by small meadow taxa (ME) and overgrown by macroforbs (MAC) in the years 2017 and 2018

\begin{tabular}{|c|c|c|c|c|c|}
\hline & & \multicolumn{4}{|c|}{ Subplots } \\
\hline & & I & II & III & IV \\
\hline \multirow[t]{2}{*}{ Year 2017} & $\mathrm{ME}$ & $\begin{array}{c}63.3 \\
( \pm 8.8)\end{array}$ & $\begin{array}{c}57.0 \\
( \pm 7.7)\end{array}$ & $\begin{array}{c}49.8 \\
( \pm 3.2)\end{array}$ & $\begin{array}{c}48.6 \\
( \pm 5.0)\end{array}$ \\
\hline & MAC & $\begin{array}{c}84.4 \\
( \pm 1.2)\end{array}$ & $\begin{array}{c}78.0 \\
( \pm 0.8)\end{array}$ & $\begin{array}{c}60.0 \\
( \pm 0.4)\end{array}$ & $\begin{array}{c}58.4 \\
( \pm 0.4)\end{array}$ \\
\hline \multirow[t]{2}{*}{ Year 2018} & ME & $\begin{array}{c}65.0 \\
( \pm 7.7)\end{array}$ & $\begin{array}{c}59.9 \\
( \pm 9.0)\end{array}$ & $\begin{array}{c}52.0 \\
( \pm 6.6)\end{array}$ & $\begin{array}{c}49.3 \\
( \pm 8.3)\end{array}$ \\
\hline & MAC & $\begin{array}{c}88.8 \\
( \pm 12.2)\end{array}$ & $\begin{array}{c}82.0 \\
( \pm 8.8)\end{array}$ & $\begin{array}{c}66.6 \\
( \pm 5.1)\end{array}$ & $\begin{array}{c}64.4 \\
( \pm 8.4)\end{array}$ \\
\hline
\end{tabular}

Table 5. The ANOVA results for factorial designs of the effect of patch and subplot character on soil humidity at ground level in the years 2017 and 2018

\begin{tabular}{|c|c|c|c|c|c|c|}
\hline & & $\begin{array}{l}\text { Sum of } \\
\text { squares }\end{array}$ & $\begin{array}{c}\text { Degrees } \\
\text { of freedom }\end{array}$ & Mean square & F-value & p-value \\
\hline \multirow[t]{5}{*}{ Year 2017} & Intercept & 402486.0 & 1 & 402486.0 & 8597.1 & $\mathrm{p}<0.001$ \\
\hline & Patch & 4374.0 & 1 & 4374.0 & 93.4 & $\mathrm{p}<0.001$ \\
\hline & Subplot & 7793.1 & 3 & 2597.7 & 55.4 & $\mathrm{p}<0.001$ \\
\hline & Patch*subplot & 353.1 & 3 & 117.7 & 2.5 & 0.33 \\
\hline & Error & 4119.8 & 88 & 46.8 & & \\
\hline \multirow[t]{5}{*}{ Year 2018} & Intercept & 451415.5 & 1 & 451415.5 & 9744.5 & $\mathrm{p}<0.001$ \\
\hline & Patch & 4774.3 & 1 & 4774.3 & 103.0 & $\mathrm{p}<0.001$ \\
\hline & Subplot & 5198.9 & 3 & 1733.0 & 37.4 & $\mathrm{p}<0.001$ \\
\hline & Patch*subplot & 135.8 & 3 & 45.3 & 0.9 & 0.71 \\
\hline & Error & 4076.6 & 88 & 46.3 & & \\
\hline
\end{tabular}


Table 6. Mean $( \pm \mathrm{SD})$ number of seedlings of Betonica officinalis. Sanguisorba officinalis and Succisa pratensis in artificial gaps made in Molinion caeruleae patch dominated by small meadow taxa (ME) and overgrown by macroforbs (MAC) appeared in subplots with no disturbance (I), removed litter and mosses (II), removed litter. mosses and aboveground organs of plants (III), removed litter. mosses aboveground organs of plants and $7 \mathrm{~cm}$ soil layer (IV in the years 2017 and 2018

\begin{tabular}{|c|c|c|c|c|c|}
\hline \multirow{2}{*}{ Species } & \multirow[t]{2}{*}{ Patch } & \multicolumn{4}{|c|}{ Subplots } \\
\hline & & $\mathbf{I}$ & II & III & IV \\
\hline \multirow{2}{*}{$\begin{array}{l}\text { Betonica } \\
\text { officinalis }\end{array}$} & ME & $\begin{array}{c}0.0 \\
( \pm 0.0)\end{array}$ & $\begin{array}{c}2.9 \\
( \pm 1.6) \\
\end{array}$ & $\begin{array}{c}31.8 \\
( \pm 21.6)\end{array}$ & $\begin{array}{c}29.9 \\
( \pm 14.6)\end{array}$ \\
\hline & MAC & $\begin{array}{c}0.0 \\
( \pm 0.0) \\
\end{array}$ & $\begin{array}{c}3.9 \\
( \pm 3.5) \\
\end{array}$ & $\begin{array}{c}22.8 \\
( \pm 8.0) \\
\end{array}$ & $\begin{array}{c}19.2 \\
( \pm 4.0) \\
\end{array}$ \\
\hline \multirow{2}{*}{$\begin{array}{c}\text { Sanguisorba } \\
\text { officinalis }\end{array}$} & ME & $\begin{array}{c}0.1 \\
( \pm 0.3) \\
\end{array}$ & $\begin{array}{c}7.4 \\
( \pm 5.0) \\
\end{array}$ & $\begin{array}{c}53.1 \\
( \pm 21.0) \\
\end{array}$ & $\begin{array}{c}37.1 \\
( \pm 11.6) \\
\end{array}$ \\
\hline & MAC & $\begin{array}{c}0.3 \\
( \pm 0.7)\end{array}$ & $\begin{array}{c}6.9 \\
( \pm 5.1)\end{array}$ & $\begin{array}{c}33.6 \\
( \pm 6.7)\end{array}$ & $\begin{array}{c}26.3 \\
( \pm 6.5)\end{array}$ \\
\hline \multirow{2}{*}{ Succisa pratensis } & ME & $\begin{array}{c}0.4 \mathrm{a} \\
( \pm 0.9)\end{array}$ & $\begin{array}{c}5.5 \mathrm{a} \\
( \pm 3.6)\end{array}$ & $\begin{array}{c}27.7 b \\
( \pm 13.4)\end{array}$ & $\begin{array}{l}20.3 \mathrm{~b} \\
( \pm 5.1)\end{array}$ \\
\hline & MAC & $\begin{array}{c}0.0 \mathrm{a} \\
( \pm 0.0)\end{array}$ & $\begin{array}{c}8.0 \mathrm{a} \\
( \pm 3.5)\end{array}$ & $\begin{array}{c}28.9 \mathrm{~b} \\
( \pm 7.3)\end{array}$ & $\begin{array}{l}20.5 b \\
( \pm 6.7)\end{array}$ \\
\hline
\end{tabular}

Table 7. The ANOVA results for factorial designs of the effect of patch and subplot character on cumulative number of seedlings Betonica officinalis. Sanguisorba officinalis and Succisa pratensis appeared in the years 2017-2018

\begin{tabular}{|c|c|c|c|c|c|c|}
\hline & & $\begin{array}{c}\text { Sum } \\
\text { of squares }\end{array}$ & $\begin{array}{c}\text { Degrees } \\
\text { of freedom }\end{array}$ & Mean square & F-value & p-value \\
\hline \multirow[t]{5}{*}{$\begin{array}{l}\text { Betonica } \\
\text { officinalis }\end{array}$} & Intercept & 37525.0 & 1 & 37525.0 & 284.8 & $\mathrm{p}<0.001$ \\
\hline & Patch & 425.0 & 1 & 425.0 & 3.2 & 0.07 \\
\hline & Subplot & 28322.0 & 3 & 9440.6 & 71.6 & $\mathrm{p}<0.001$ \\
\hline & Patch*subplot & 894.3 & 3 & 298.1 & 2.2 & 0.08 \\
\hline & Error & 11591.5 & 88 & 131.7 & & \\
\hline \multirow[t]{5}{*}{$\begin{array}{c}\text { Sanguisorba } \\
\text { officinalis }\end{array}$} & Intercept & 71668.0 & 1 & 71668.0 & 552.4 & $\mathrm{p}<0.001$ \\
\hline & Patch & 1283.3 & 1 & 1283.3 & 9.8 & $\mathrm{p}<0.001$ \\
\hline & Subplot & 46317.2 & 3 & 15439.0 & 119.0 & $\mathrm{p}<0.001$ \\
\hline & Patch*subplot & 1549.6 & 3 & 516.5 & 3.9 & $\mathrm{p} \leq 0.05$ \\
\hline & Error & 11416.7 & 88 & 129.7 & & \\
\hline \multirow[t]{5}{*}{ Succisa pratensis } & Intercept & 40016.6 & 1 & 40016.6 & 618.8 & $\mathrm{p}<0.001$ \\
\hline & Patch & 126.0 & 1 & 126.0 & 1.9 & 0.16 \\
\hline & Subplot & 22369.0 & 3 & 7456.3 & 115.3 & $\mathrm{p}<0.001$ \\
\hline & Patch*subplot & 115.8 & 3 & 38.6 & 0.5 & 0.61 \\
\hline & Error & 5690.3 & 88 & 64.6 & & \\
\hline
\end{tabular}


each pair of subplots. The recruitment of seedlings Sanguisorba officinalis differed significantly among study sites and subplots (Table 6). The statistical analysis showed the significant, independent influence of patch character and subplot type, as well as the significant effect of their interaction (Table 7). The Tukey HSD test showed remarkable differences among number of seedlings recorded in subplot III in Patch ME and all other subplots $(\mathrm{p}<0.001)$, as well as among subplot IV in Patch ME and other subplots in Patch ME $(\mathrm{p}<0.001)$ and subplots I, II in Patch MAC $(p<0.001)$. Simultaneously, the number of seedling noticed in subplots I and II in both Patches was similar.

\section{Discussion}

\subsection{The habitat conditions}

The performed showed that light intensity at ground surface and soil moisture shows spatial variability. The light intensity at the ground level increased from subplot I (control), via II (without litter and moss layer), to III (without litter, moss layer and aboveground parts of plants) and IV (without litter, moss layer, above- and belowground parts of plants and topsoil), while the soil humidity showed a reverse trend. This phenomenon corresponds with the findings conducted in various habitats, proving that increasing vegetation cover results in the decreasing light availability at ground level (Jutila \& Grace, 2002; Prévost, 2008) and augmentation of soil moisture (Edwards et al., 2003; Duan et al., 2011).

The observed, remarkably greater light availability at the soil surface within subplots I and II in Patch ME might be due to greater absorption of solar radiation by the dense leaf canopy of grasses and macroforbs growing within the subplots in Patch MAC. According to other authors (Fliervoet \& Werger, 1984; Kotowski \& van Diggelen, 2004), the increased canopy height in wet meadows can considerably reduce incident radiation. The lack of differences among the Patches in subplots III and IV might be connected with the cutting and uprooting of plants in the first year of observations, as well as the quite similar height of recolonisers (personal observation), allowing a similar amount of solar radiation reaching the soil surface. The higher soil humidity recorded in all the subplots within Patch MAC, as compared to Patch ME, might be an effect of the occurrence of local depressions among the tussocks, where water might stagnate, assuring the hydration of the ground. Moreover, the presence of tussock graminoids can increase the soil moisture due to a reduction of evaporation rates under the leaf canopy (Davie et al., 2006), as well as interception and storage of rain and fog on the stems and leaves (Ingraham et al., 2008). Furthermore, the greater soil humidity in Patch MAC might be triggered by the greater height of standing vegetation surrounding the subplots. A positive correlation between the height of the plant canopy and soil moisture was observed in subalpine grasslands (Gross et al., 2008). The removal of the plant canopy in subplots III and IV in both Patches during the first year exposed the ground to much more sunlight, facilitating water transpiration and causing a sharp lowering of ground moisture.-

\subsection{The seedling recruitment}

The performed observations showed that the number of seedlings of all the studied taxa is much smaller in subplots I and II than in subplots III and IV. The lack of differences among subplots I and II corresponds with the investigations of Wellstein (2012), who observed a similar emergence of Sanguisorba officinalis seedlings under moist conditions in places with and without litter, while Jensen and Gutekuns (2003) observed that litter might substantially reduce the recruitment rates. The substantial recruitment of seedlings in subplot III corresponds with observations showing that the removal of the vegetation canopy improves germination of B. officinalis (Špačková et al., 1998) and S. pratensis (Isselstein et al., 2002; Stammel et al., 2006) in fen meadows. Furthermore, the obtained outcomes showing the greatest recruitment rates in subplots III and IV support the results of the sowing experiments of Kotorová and Lepš (1999), who found much greater seedling number of Betonica officinalis, Sanguisorba officinalis and Succisa pratensis in mown locations, as well as in gaps created by sod stripping, than in sites with untouched vegetation of Molinion meadows. In addition, Soons et al. (2005) observed that topsoil removal contributes to an increase of seedling recruitment of $S$. pratensis from sown seeds. On the other hand, Dorland et al. (2003) argued that sod cutting might contribute to the accumulation of ammonium, thus hampering the seedling recruitment of Succisa pratensis.

The substantial colonization rates found in subplot III might be enhanced by the absence of moss, litter and aboveground plant organs hampering the germination of seeds deposited on the soil surface, whilst the successful seedling recruitment noticed in subplot IV might be additionally facilitated by lack of belowground parts of the plants. The considerable recruitment rates of all the studied species in subplot IV might suggest the germination of seeds deposited in seed bank occurring in deeper layers of the soil. On the other hand, Burmeier et al. (2010) observed the low survivability rate of buried Sanguisorba officinalis seeds, whilst other authors noted that the probability of survival of Succisa pratensis seeds decreases with augmentation of the burial period (Mildén et al., 2006; Wallin et al., 2009; Kaiser \& Pirhofer-Walzl, 2015), and after 1 year it reaches $100 \%$ (Jensen, 2004). The substantial number of 
seedlings of all the studied taxa in subplot IV might indicate the immediate germination of dispersed seeds after reaching the openings. Such a supposition is supported by laboratory tests (Grime et al., 1981; Holloway \& Matheke, 2003), but the recruitment rates might be diminished by the post dispersal seed losses caused, for instance, by predation (Jongejans et al., 2006).

The performed observations showing remarkable effect of patch character on number of seedlings Sanguisorba officinalis corresponds with the findings of Musche et al. (2008). The aforementioned author evidenced that the percentage of germination of Sanguisorba officinalis decreased in small and low-density populations as an effect of restricted occurrence of the pollinators Maculinea nausithous and Maculinea teleius in sites where the plant occurs at low numbers, leading to lower seed production. Additionally, it is worth mentioning that noticed in presented investigations significant simultaneous effect of the patch character and the subplot type on recruitment of Sanguisorba officinalis seedlings needs further observations.

\section{Conclusions}

The study confirmed, that the disturbance intensity influence on spatial variability of light intensity and ground moisture in two patches of Molinion meadows with different dominant species. The seedlings recruitment of all species was much lower in subplots I (control) and II (weak disturbance), than in subplots III (intermediate disturbance) and IV (strong disturbance). The intermediate and strong disturbances - diminishing competition from standing vegetation within the subplots and enabling substantial light penetration - contribute to the greatest seedling recruitment. The obtained results might provide a basis for successful plans of enlargement of natural resources of medicinal plants in Molinia meadows-one of most valuable semi-natural communities in Europe.

\section{Acknowledgements}

I would like thank to the anonymous Referees for their useful suggestions.

\section{References}

Adams A.W. 1955, Succisa pratensis Moench. (Scabiosa succisa L.). Journal of Ecology 43(2): 709-18.

Anonymous, 1992, Council Directive 92/43/EEC of 21 May 1992 on the Conservation of Natural Habitats and of Wild Fauna and Flora. Official Journal L 206: 7-50.
Anonymoyus, 1997, Council Directive 97/62/EC of 27 October 1997 Adapting to Technical and Scientific Progress Directive 92/43/EEC on the Conservation of Natural Habitats and of Wild Fauna and Flora, Official Journal L 305, 42-65.

Anonymous, 1997, Ängsvädd Succisa pratensis Moench. (http://linnaeus.nrm.se/flora/di/dipsaca/succi/succpra. html), [Accessed on 20 Febuary 2019].

Anonymous, 1998a, Humlesuga Stachys officinalis (L.) Trevis. (http://linnaeus.nrm.se/flora/di/lamia/stach/stacoff.html), [Accessed on 20 Febuary 2019].

Anonymous, 1998b, Blodtopp Sanguisorba officinalis L. (http://linnaeus.nrm.se/flora/di/rosa/sangu/sangoff. html), [Accessed on 20 Febuary 2019].

Anonymous, 2007, Interpretation Manual of European Union Habitats, European Commission Dg Environment, Nature and biodiversity EUR 27. (http://ec.europa. eu/environment/nature/legislation/habitatsdirective/ docs/2007 07 im.pdf), [Accessed 20 Febuary 2019].

Bornand C., Gygax A., Juillerat P., Jutzi M., Möhl A., Rometsch S., Sager L., Santiago H., Eggenberg S., 2016, Liste Rouge Plantes Vasculaires. Espèces Menacées en Suisse [Red List of Vascular Plants. Threatened Species in Switzerland]. Office fédéral de l'environnement, Berne et Info Flora, Genève, Switzerland.

Burmeier S., Donath T.W., Otte A. \& Eckstein R.L., 2010, Rapid burial has differential effects on germination and emergence of small- and large-seeded herbaceous plant species. Seed Science Research 20: 189-200.

Csapodý V., 1968, Keimlingsbestimmungsbuch der Dikotyledonen. Akademiai Kiado, Hungary.

Davie T.J.A., Fahey B.D. \& Stewart M.K. 2006, Tussock grasslands and high water yield: a review of the evidence. Journal of Hydrology 45(2): 83-93.

Dorland E., Bobbink, R., Messelink, J.H., \& Verhoeven, J.T.A., 2003, Soil ammonium accumulation after sod cutting hampers the restoration of degraded wet heathlands. Journal of Applied Ecology 40: 804-814.

Duan L., Liu T., Wang X., Wang G., Ma L. \& Luo Y., 2011, Spatio-temporal variations in soil moisture and physicochemical properties of a typical semiarid sandmeadow-desert landscape as influenced by land use. Hydrology and Earth System Sciences 15: 1865-1877.

Edwards J., Giles M. \& Tindal C., 2003, The effects of burning and mowing on soil moisture, soil $\mathrm{pH}$, and percent of carbon and nitrogen in soil and Andropogon gerardi. Tillers 4: 15-19.

Errikson O. \& Fröborg H., 1996, "Windows of opportunity" for recruitment in long-lived clonal plants: experimental studies of seedling establishment in Vaccinium shrubs. Canadian Journal of Botany 74(9): 1369-1374.

Fitter A.H. \& Peat H.J., 1994, The Ecological Flora Database. Journal of Ecology 82: 415-425. 
Fliervoet L.M. \& Werger M.J.A., 1984, Canopy structure and microclimate of two wet grassland communities. New Phytologist 96: 115-130.

Grime J.P., Mason G., Curtis A.V., Rodman J., Band S.R., Mowfort M.A.G., Neal A.M. \& Shaw S., 1981, A comparative study of germination characteristics in a local flora. Journal of Ecology 69(3):1017-59.

Gross N., Robson T.M., Lavorel S., Albert C., Le BagoussePinguet Y. \& Guillemin R., 2008, Plant response traits mediate the effects of subalpine grasslands on soil moisture. New Pytologist 180(3): 652-662.

Harper J.L., Williams J.T. \& Sagar G.R., 1965, The behaviour of seeds in soil: I. The heterogeneity of soil surfaces and its role in determining the establishment of plants from seed. Journal of Ecology 53: 273-286.

Holloway P. \& Matheke G.E.M., 2003, Seed germination of burnet, Sanguisorba spp, Native Plants Journal 4(2): 95-99.

Ingraham N.L., Mark A.F. \& Frew R.D., 2008, Fog deposition by snow tussock grassland on the Otago uplands: response to a recent review of the evidence. Journal of Hydrology 47(2): 107-122.

Isselstein J., Tallowin J.R.B. \& Smith, R.E.N., 2002, Factors affecting seed germination and seedling establishment of fen-meadow species. Restoration Ecology 10: 173-184.

Janeček S. \& Lepš J., 2005, Effect of litter, leaf cover and cover of basal internodes of the dominant species $\mathrm{Mo}$ linia caerulea on seedling recruitment and established vegetation. Acta Oecologica 28(2): 141-147.

Jensen K., 2004, Dormancy patterns, germination ecology, and seed-bank types of twenty temperate fen grassland species. Wetlands 24(1):152-166.

Jensen K. \& Gutekuns K., 2003, Effects of litter on establishment of grassland plant species: the role of seed size and successional status, Basic and Applied Ecology 4: 579-587.

Jongejans E., Soons M.B. \& de Kroon H., 2006, Bottlenecks and spatiotemporal variation in the sexual reproduction pathway of perennial meadow plants. Basic Appl. Ecol. 7: 71-81.

Jutila H.M. \& Grace J.B., 2002, Effects of disturbance on germination and seedling establishment in a coastal prairie grassland: a test of the competitive release hypothesis. Journal of Ecology 90(2): 291-302.

Kaiser T. \& Pirhofer-Walzl K., 2015, Does the soil seed survival of fen-meadow species depend on the groundwater level? Plant Soil 387(1-2): 219-231.

Kleyer M., Bekker R.M., Knevel I.C., Bakker J.P, Thompson K., Sonnenschein M., Poschlod P., Van Groenendael J.M., Klimeš L., Klimešová J., Klotz S., Rusch G.M., Hermy M., Adriaens D., Boedeltje G., Bossuyt B., Dannemann A., Endels P., Götzenberger L., Hodgson J.G., Jackel A-K., Kühn I., Kunzmann D., Ozinga
W.A., Römermann C., Stadler M., Schlegelmilch J., Steendam H.J., Tackenberg O., Wilmann B., Cornelissen J.H.C., Eriksson O., Garnier E. \& Peco B., 2008, The LEDA Traitbase: A database of life-history traits of Northwest European flora. Journal of Ecology 96: 1266-1274.

Kostrakiewicz K., 2011, The effect of gaps size on colonization process in Molinietum caeruleae meadows with different habitat conditions. Polish Journal of Ecology 59(4): 677-686.

Kostrakiewicz-Gierałt K., 2012, The impact of neighborhood and gap character on seedling recruitment of Trollius europaeus L., and Iris sibirica L, in Molinietum caeruleae meadows. Biodiversity: Research and Conservation 28: 37-44.

Kostrakiewicz-Gierałt K., 2014a, The effect of neighbouring plant height, disturbance level and gap size on spontaneous recruitment of large-seeded and small-seeded species in Molinietum caeruleae meadows. Polish Journal of Ecology 62(2): 289-306.

Kostrakiewicz-Gierałt K., 2014b, The effects of successional stage and size of gaps on recruitment of clonal plants in overgrowing Molinietum caeruleae meadows. Acta Agrobotanica 67(4): 87-98.

Kostrakiewicz-Gierałt K., 2015a, The impact of time of gap origin on microsite conditions and seedling recruitment in Molinietum caeruleae meadows. International Journal of Conservation Science 6(1): 111-124.

Kostrakiewicz-Gierałt K., 2015b, The effect of the shape of gaps on microenvironmental conditions and seedling recruitment in Molinietum caeruleae meadows. Acta Agrobotanica 68(2):143-151.

Kostrakiewicz-Gierałt K., 2017a, The influence of vegetation structure on the composition of the seed rain and seedling pool in abandoned Molinion caeruleae meadows. Polish Journal of Ecology 65: 269-284.

Kostrakiewicz-Gierałt K., 2017b, The effect of succession stage on seed rain and seedling recruitment in overgrown Molinia caeruleae meadows. Archives of Biological Sciences 69(3): 513-522.

Kostrakiewicz-Gierałt K., 2018, The impact of succession stage on share and traits of clonal plants in abandoned Molinion caeruleae meadows. Russian Journal of Ecology 49(1): 47-52.

Kotorová I. \& Lepš J., 1999, Comparative ecology of seedling recruitmentin an oligotrophic wet meadow, Applied Vegetation Science 10: 175-186.

Kotowski W. \& van Diggelen R., 2004, Light as an environmental filter in fen vegetation. Journal of Vegetation Science 15(5): 583-594.

Křenová Z. \& Lepš J., 1996, Regeneration of a Gentiana pneumonanthe population in an oligotrophic wet meadow. Journal of Vegetation Science 7(1): 107-112. 
Kubíková P. \& Zeidler M., 2011, Habitat demands and population characteristics of the rare plant species Gladiolus imbricatus L. in the Frenštát region (NE Moravia, the Czech Republic). Casopis Slezského Zemského Muzea Opava (A), 60: 154-164.

Lazarević J.S., Dordević A.S., Kitić D.V., Zlatković B. \& Stojanović G.S., 2013, Chemical composition and antimicrobial activity of thee essential oil of Stachys officinalis (L.) Trevis. (Lamiaceae). Chemistry and Biodiversity 10: 1335-1349.

Lepš J., 1999, Nutrient status, disturbance and competition: an experimental test of relationships in a wet meadow. Journal of Vegetation Science 10(2): 219-230.

Lepš J., 2014, Scale- and time-dependent effects of fertilization, mowing and dominant removal on a grassland community during a 15-year experiment. Journal of Applied Ecology 51: 978-987.

Matuszkiewicz W., 2008, Przewodnik do oznaczania zbiorowisk roślinnych Polski [A Guide to Identification of Polish Plant Communities]. Wydawnictwo Naukowe PWN, Warszawa.

Mildén M., Münzbergová Z., Herben T. \& Ehrlén J., 2006, Metapopulation dynamics of a perennial plant, Succisa pratensis, in an agricultural landscape. Ecological Modelling 199(4): 464-475.

Mudrák O., Doležal J., Hájek M., Dančák M., Klimeš L. \& Klimešová J., 2013, Plant seedlings in a species-rich meadow: Effect of management, vegetation type and functional traits. Applied Vegetation Science 16(2): 286-295.

Muller F.M., 1978, Seedlings of the NorthWestern European lowland. A flora of seedlings. Dr W. Junk B.V. Publishers, The Hague, Boston, Centre for Agricultural Publishing and Documentation, Wageningen.

Musche M., Settele J. \& Durka W., 2008, Genetic population structure and reproductive fitness in the plant Sanguisorba officinalis in populations supporting colonies of an endangered Maculinea butterfly. International Journal of Plant Sciences 169(2): 253-262.

Pladias, 2014-2018. Database of the Czech flora and vegetation. (www.pladias.cz), [Accessed 20 Febuary 2019]

Prévost M., 2008, Effect of cutting intensity on microenvironmental conditions and regeneration dynamics in yellow birch - conifer stands. Canadian Journal of Forest Research, 38(2): 317-330.

Royal Botanic Gardens Kew, 2018, Seed Information Database (SID). Version 7.1. (http://data.kew.org/sid/), [Accessed 20 Febuary 2019].

Soons M.B., Messelink J. H., Jongejans E. \& Heil G.W., 2005, Habitat fragmentation reduces grassland connectivity for both short-distance and long-distance winddispersed forbs. Journal of Ecology 93: 1214-1225.
Špačková I., Kotorová I. \& Lepš J., 1998, Sensitivity of seedling recruitment to moss, litter and dominant removal in an oligotrophic wet meadow. Folia Geobotanica 33(1): 17-30.

Špačková I. \& Lepš J., 2004, Variability of seedling recruitment under dominant, moss, and litter removal over four years. Folia Geobotanica 39(1): 41-55.

Sparrius L.B., Odé B. \& Beringen R., 2014, Basisrapport Rode Lijst Vaatplanten 2012 Volgens Nederlandse en IUCN-criteria. Floron, Nijmegen, Netherlands.

Stroh P.A., Leach S.J., August T.A., Walker K.J., Pearman D.A., Rumsey F.J., Harrower C.A., Fay M.F., Martin J.P., Pankhurst T., Preston C.D. \& Taylor I., 2014, A Vascular Plant Red List for England. Botanical Society of Britain and Ireland, Bristol.

Stammel B., Kiehl K. \& Pfadenhauer J., 2006, Effects of experimental and real land use on seedling recruitment of six fen species. Basic and Applied Ecology 7(4): 334-346.

Su X.D., Guo R.H., Li H., Ma J.Y., Kim Y.R., Kim Y.H. \& Yang S.Y., 2018, Anti-allergic inflammatory components from Sanguisorba officinalis L. Bioorganic \& Medicinal Chemistry Letters 28(12): 2210-2216.

Těšitel J., Mladek J., Horník J., Těšitelová T., Adamec V. \& Tichý L., 2017, Suppressing competitive dominants and community restoration with native parasitic plants using the hemiparasitic Rhinanthus alectorolophus and the dominant grass Calamagrostis epigejos. Journal of Applied Ecology 54(5): 1-9.

Wallin L., Svensson B.M. \& Lönn M., 2009, Artificial dispersal as a restoration tool in meadows: sowing or planting? Restoration Ecology 17(2): 270-279.

Wellstein C., 2012, Seed-litter-position drives seedling establishment in grassland species under recurrent drought. Plant Biology 14(6): 1006-1010.

Wilhalm T. \& Hilpold A., 2006, Rote Liste der gefährdeten Gefäßpflanzen Südtirols [List of Endangered Vascular Plants of South Tyrol]. Gredleriana 6: 115-198.

Witkowska-Banaszczak E. \& Długaszewska J., 2017, Essential oils and hydrophilic extracts from the leaves and flowers of Succisa pratensis Moench. and their biological activity. Journal of Pharmacy and Pharmacology 69: 1531-1539.

Wyse Jackson M., FitzPatrick Ú., Cole E., Jebb M., McFerran D., Sheehy Skeffington M. \& Wright M., 2016, Ireland Red List No. 10: Vascular Plants. National Parks and Wildlife Service. Department of Arts, Heritage, Regional, Rural and Gaeltacht Affairs, Dublin, Ireland.

Zhang H.F., Chen J.J., Cen Y., 2018, Burn wound healing potential of a polysaccharide from Sanguisorba officinalis L. in mice. International Journal of Biological Macromolecules 112: 862-867. 